\title{
Nitric oxide monocyte production levels in patients with the hepatosplenic form of Scistosoma mansoni infection who underwent splenectomy, ligature of the left gastric vein and auto implantation of spleen tissue in the major omentum ${ }^{1}$
}

\author{
Níveis de óxido nítrico produzidos por monócitos em portadores de esquistossomose \\ hepatoesplênica que se submeteram a esplenectomia, ligadura da veia gástrica \\ esquerda e auto-implante de tecido esplênico no omento maior
}

\author{
Carlos Teixeira Brandt ${ }^{2}$, Carlos Roberto Carvalho Leite ${ }^{3}$, Francisco Machado Manhaes-de-Castro ${ }^{4}$, Érika Michelle \\ Correia de Macedo ${ }^{4}$, Rebecca Peixoto Paes Silva ${ }^{4}$, Célia Maria Machado Barbosa de Castro \\ 1. Department of Surgery, Pediatric Surgery Division and Laboratory of Immunology and Pathology Keijo Assami (LIKA), Federal \\ University of Pernambuco (UFPE), Brazil. \\ 2. Full Professor, Ph.D, Head Division of Pediatric Surgery, Health Sciences Center, UFPE, Brazil. \\ 3. Master of Sciences in Surgery, UFPE, Brazil. \\ 4. Medical Student, Scholarship in Research from the Brazilian National Research Council (CNPq), UFPE, Brazil. \\ 5. Associate Professor in Tropical Medicine, Ph.D, Health Sciences Center, UFPE, Brazil.
}

\begin{abstract}
Purpose: To measure the levels of NO production by monocytes in patients with the hepatosplenic form of schistosomiasis mansoni who underwent splenectomy, ligature of the left gastric vein and auto implantation of spleen tissue in the major omentum. Methods: Four groups of volunteers were enrolled in the investigation: G1 - 12 patients with $S$. mansoni infection in its hepatosplenic form without any kind of treatment (SMH); G2 - 13 SMH patients who underwent medical treatment and portal hypertension decompression - splenectomy and ligature of the left gastric vein (SMH/SLGV); G3 - 19 patients similar to the later group, but additionally received auto implantation of spleen morsels in the major omentum (SMH/SLGV/AI); and G4 - 15 individuals with no S. mansoni infection coming from the same geographical area and presenting similar socio economical status (CG). Nitrite production by monocytes was determined by a standard Griess reaction adapted to microplates. The results were presented by mean $\pm \mathrm{SD}$ for each group. Significant differences in NO production by monocytes were determined by Tukey-Kramer multicomparisons test. Probability values of 0.05 were considered significant. Results: Patients from G1 (SMH) showed lower level of NO production by monocytes $(5.28 \pm$ $1.28 \mu \mathrm{mol} / \mathrm{ml})$. Patients from G2 (SMH/SLGV) showed similar results $(6.67 \pm 0.44 \mu \mathrm{mol} / \mathrm{ml}-\mathrm{q}=2.681 \mathrm{p}>0.05)$. Individuals of G4 (CG) showed higher level of NO production by monocytes $(8.19 \pm 2.74 \mu \mathrm{mol} / \mathrm{ml})$. Patients from G3 (SMH/SGLV/AI) showed similar NO production by PBMC as compared to individuals of G4 $(\mathrm{CG})-(7.41 \pm 1.65 \mu \mathrm{mol} / \mathrm{ml}-\mathrm{q}=1.615 \mathrm{p}>0.05)$. The volunteers from G4 (CG) and G3 (SMH/SLGV/AI) showed significantly greater levels of NO production by monocytes as compared to those from $\mathrm{G} 1(\mathrm{SMH})-(\mathrm{q}=5.837 \mathrm{p}<0.01$, and $\mathrm{q}=4.285 \mathrm{p}<0.05)$. Conclusion: Collectively, the results point to a restoration of NO normal production by monocytes in SHM patients who underwent medical and surgical treatments, especially in those who had received auto implantation of spleen tissue in the major omentum after splenectomy and ligature of the left gastric vein. The data gives further support to the hypothesis that this additional procedure is important in the restoration of the immune response of these patients, since NO synthesis by the monocytes correlates with protective immunity against infection; thus, protecting them against overwhelming post splenectomy infection.
\end{abstract}

Key words: Schistosomiasis. Splenectomy. Nitric, Oxide.

\section{RESUMO}

Objetivo: Mensurar os níveis de produção de ON por monócitos do sangue periférico (MSP) em portadores de esquistossomose na forma hepatoesplênica que tinham se submetido a esplenectomia, ligadura da veia gástrica esquerda e auto-implante de tecido esplênico no omento maior. Métodos: Quatro grupos de voluntários foram envolvidos na investigação: G1 - 12 portadores de esquistossomose hepatoesplênica sem nenhuma forma de tratamento (EHE); G2 - 13 portadores de EHE que receberam tratamento clínico e se submeteram cirurgia para descompressão do sistema porta esplenectomia e ligadura da veia gástrica esquerda (EHE/ELGE); G3 - 19 pacientes similares ao do último grupo, mas que receberam também auto-implante de fragmentos de tecido esplênico no omento maior (EHE/ELGE/AI); e G4 - 15 indivíduos sem infecção pelo $S$. mansoni advindos da mesma área geográfica e apresentando as mesmas condições sócio-econômicas (GC). A produção de ON pelos MSP foi determinada pela reação padrão de Griess, adaptada para poços em microplaca. Os resultados foram expressos por suas médias \pm DP para cada grupo. Diferenças significantes nas medias de produção de ON pelos MSP foram determinadas pelo teste de comparações múltiplas de Tukey-Kramer. Foram aceito os limites de 
significância de $p<0,05$. Resultados: Os pacientes portadores de EHE não tratados (G1) evidenciaram os níveis mais baixos de produção de ON pelos MSP $(5,28 \pm 1,28 \mu \mathrm{mol} / \mathrm{ml})$. Os pacientes do G2 (EHE/ELGE) evidenciaram resultados similares $(6,67 \pm 0,44 \mu \mathrm{mol} / \mathrm{ml}-\mathrm{q}=2,681 \mathrm{p}>0.05)$. Os indivíduos do $\mathrm{G} 4$ (GC) evidenciaram os mais altos níveis de produção de ON pelos MSP $(8,19 \pm 2,74 \mu \mathrm{mol} / \mathrm{ml})$. Os pacientes do G3 (EHE/ELGE/AI) evidenciaram produção de ON produzido pelos MSP similares aos indivíduos do G4 (GC) - $(7.41 \pm 1.65 \mu \mathrm{mol} / \mathrm{ml}-\mathrm{q}=1.615 \mathrm{p}>0.05)$. Os voluntários do G4 (GC) e os do G3 (EHE/ELGE/AI) evidenciaram de forma significante maiores níveis de produção de ON pelos MSP quando comparados com os voluntários daquele do G1 (EHE) $-(q=5.837 p<0.01$, e $q=4.285 p<0.05)$. Conclusão: De forma coletiva, os resultados apontam para o restabelecimento da normalidade da produção de ON pelos MSP dos portadores de EHE que receberam tratamento clínico e se submeteram ao tratamento cirúrgico, especialmente, aqueles que receberam auto-implante de fragmentos de tecido esplênico no omento maior após esplenectomia e ligadura da veia gástrica esquerda. Os dados dão suporte adicional à hipótese de que esse procedimento adicional é importante no restabelecimento da resposta imune desses pacientes, desde que a síntese de ON pelos MSP se correlaciona com a imunidade protetora contra infecção; dessa forma, protegendo-os contra infecção disseminada após esplenectomia.

Descritores: Esquistossomose. Esplenectomia. Óxido Nítrico.

\section{Introduction}

Schistosomiasis is a millenary disease, which affects more the 200 million individuals distributed in 76 countries in Africa, Asia or America. Among these, $10 \%$ present the severe form of disease and 50 to $60 \%$ of infected people (more than 100 million) present clinical manifestation of the disease, constituting a huge public health problem ${ }^{1}$. In Brazil, the Schistosomiasis Control Program has been very successful in reducing infection prevalence but did not interrupt transmission, nor reduced prevalence rate to less than $5 \%$. In the Northeastern region of Brazil occurs the greatest prevalences ${ }^{2}$. The reduction of morbid-mortality of this infection results from massive use of oxamniquine and praziquantel treatment ${ }^{2}$. As regard to Scistosoma mansoni infection in Pernambuco State-Northeast Brazil, a spatial analysis reveals that although from 1995 to 1999 there was a spread of admissions due to this condition in the municipalities (counties) of "Sertão" (backlands or countryside) and São Francisco river valley, the number of municipalities with hospitalizations due to schistosomiasis decreased from 1995 to 1998, followed by an increase in 1999 and $2000^{3}$. In this State the surgical treatment for the portal hypertension in the hepatosplenic form includes splenectomy and ligature of the left gastric vein ${ }^{4}$; in children, auto implantation of spleen tissue in the major omentum is added ${ }^{5}$. The risk of severe infection is an important health problem in splenectomized patients, greater in children, but still present in adults with the overall rate of 7.0 per 100 persons-years $(95 \%$ confidence interval, $6.30-7.78)^{6}$. The immune protective effects of the splenosis after spleen tissue auto implantation in children with mansoni schistosomiasis who underwent splenectomy has been studied, but although several studies ${ }^{7,8}$ have given support to the concept that the maintenance of residual immune function after auto implantation of spleen tissue is beneficial against overwhelming postoperative severe infection, the subject is still matter of controversy when the monocytes of these patients are submitted to stress ${ }^{8}$. The fundamental initiating factor in portal hypertension of patients with mansoni schistosomiasis is an increase in resistance to portal venous flow. Portal venous pressure rises as a consequence, and collateral channels open to decompress the portal venous system. A number of secondary haemodynamic phenomena occurs with portal hypertension. Systemic vascular resistance and mean arterial blood pressure fall and both cardiac vascular output and splancnic blood flow increase. Current theories suggest that increased vascular production of nitric oxide (NO) may have a principal role in the pathogenesis of these secondary haemodynamic changes ${ }^{9}$. NO production is also known to increases following the deposition of parasite eggs in the liver during the infection with Schistosoma mansoni in mice and remains elevate until death. In these animals increased NO production by cultured spleen cells correlated tightly with increased disease severity suggesting a deleterious role for this mediator. Defining the role of NO during schistosomiasis disease has become particularly relevant in light of recent findings showing that peripheral blood mononuclear cells (PBMC) from infected patients are capable of in vitro NO production following exposure to $S$. mansoni antigens ${ }^{10}$. It has been observed that the absence of NO during acute schistosomiasis leads to increased hepatic damage characterized by hepatocyte apoptosis and increased hepatocellular enzyme release ${ }^{11}$. These findings are supportive of the proposed protective role for NO in preventing hepatocyte damage induced by TNF-alpha and oxygen radicals ${ }^{12}$. On the other hand, NO seems to be pivotal in the regulation of granulomatous responses to liver involvement of the $S$. mansoni infection ${ }^{13,14}$. As regard to overwhelming infection $\mathrm{NO}$ is believed to play a key role in the pathogenesis of septic shock, although many aspects of the involvement of NO remain poorly defined. The elevated circulating nitrite/nitrate - the stable byproducts of NO observed in septic patients combined with the reduction in vascular tone seen after endotoxin or proinflammatory cytokine administration, and the identification of endothelium-derived relaxing factor (EDRF) as $\mathrm{NO}^{15},{ }^{16}$ led to the suggestion that $\mathrm{NO}$ is involved in the cardiovascular alterations of septic shock ${ }^{17}$. The purpose of the present investigation was to evaluate the levels of nitric oxide produced by cultured monocytes of patients suffering from the hepatosolenic form of schistosomiasis mansoni in adolescents and young adults, who underwent splenectomy, ligature of the left gastric vein and auto implantation of spleen morsels in the major omentum.

\section{Methods}

The study was prospective and performed at the Department of Surgery (Pediatric Surgery Division) and Laboratory of Immunology Keijo Assami (LIKA) - Federal University of Pernambuco (UFPE). 


\section{Patients}

G1 - 12 patients with $S$. mansoni infection in its hepatosplenic form without any kind of treatment (SMH). Ten were females and two males. Ages varied from 10 to 30 years $($ Mean $=20.0 \pm 2.1$ years). All patients came from endemic area for $S$. mansoni. Kato-Katz was positive in each patient (Group with active disease).

G2 - 13 SMH patients, similar to G1, but presented upper digestive bleeding. Nine were females and four were males. Ages varied from 18 to 30 years $($ Mean $=24.6 \pm 3.4$ years). They underwent medical treatment and portal hypertension decompression - splenectomy and ligature of the left gastric vein (Reference Group - SMH/SLGV).

G3 - 19 patients clinically similar to the ones in G2. Thirteen were females and six were males. Ages varied from 16 to 25 years $($ Mean $=20.2 \pm 3.6$ years $)$. All of them received pre-operative medical treatment with a single dose of oxaminiquine $20 \mathrm{mg} / \mathrm{Kg}$. They underwent splenectomy, ligature of the left gastric vein and auto-implantation of ten slices of spleen tissue, without the capsule, into an omental pouch in the major omentum. The measurements and weights of the implanted slices were approximately: 3 × 2 × 2 $\mathrm{cm}$ and $10 \mathrm{~g}$ each. In this regard all patients in this group presented satisfactory splenosis assed by nuclear medicine (Study Group - SMH/SLGV/AI). Patients presenting recurrent upper digestive hemorrhage in the follow-up were included in the protocol for endoscopic sclerosis of esophageal varices. The patients of this group underwent colonoscopy every year in the postoperative follow-up, which average in this group is seven years, for continuous observation of the colopathy, and also for assessing residual infection of S.mansoni by the quantitative egg count in a routine three submucosal colon biopsies. Five patients $(26.3 \%)$ with positive viable eggs received a second medical treatment with praziquantel in a single dose of $30 \mathrm{mg} /$ $\mathrm{Kg}$. Laboratory investigation in this group included liver function tests for assessing hepatic functional reserve. Before medical and surgical treatment $14(73.7 \%)$ patients were classified as Child-Pugh A and 5 (26.3\%) were ChildPugh B. In the last post-operative follow-up evaluation 17 (89.5\%) patients were Child-Pugh A and 2 (10.5\%) were ChidPugh B.

G4 - 15 individuals without S. mansoni infection. They lived in the same geographical area, and presenting similar socio economical status of patients enrolled in groups G1, G2 and G3. Eight were females and seven were males. Ages varied from 15 to 28 years (Mean $=19.3 \pm 4.3$ years $)$ - (Control Group - CG). All patients were cared for at the University Hospital (Hospital das Clínicas), Federal University of Pernambuco, Brazil.

Obtaining monocytes from the mononuclear cells of peripheral blood (PBMC): 15-mL samples of whole blood were aseptically collected by peripheral venous puncture in a vautainer tube with EDTA. Next, after being placed in 50-mL Ficoll tubes (Talpiot Industrial, Israel) with a phosphate buffer (PBS - $0.01 \mathrm{M}$ ) to reach a volume of 45 $\mathrm{mL}$, the samples were centrifuged for 30 minutes $(1200 \mathrm{rpm}$, $2^{\circ}$ to $8^{\circ} \mathrm{C}$ ). The aspirated plasmas and layers of PBMC were then collected and transferred to $50-\mathrm{mL}$ sterile centrifuge tubes (Corning Incorporated, USA), to reach a volume of $45 \mathrm{~mL}$ once again with PBS $(0.01 \mathrm{M})$. Two further lavages were performed and the precipitates resuspended in $2 \mathrm{~mL}$ RPMI 1640 culture medium, supplemented with $3 \%$ bovine fetal serum, $100 \mathrm{U} / \mathrm{mL}$ of penicillin and $100 \mathrm{mg} / \mathrm{mL}$ of streptomycin. Next, PBMC were counted in a Neubuer chamber. The cell concentrations were adjusted to $1.0 \times 10^{6}$ cells in $1 \mathrm{~mL}$ of culture médium. After being placed on plates, $1 \mathrm{~mL}$ was dispensed from the suspension $\left(1.0 \times 10^{6}\right.$ cells for $1 \mathrm{~mL}$ of RPMI 1640) in each well and transferred to a sterilizer in a humid environment at $37^{\circ}$ with $5 \%$ of $\mathrm{CO} 2$ for 1 hour. Next, following lavages performed with RPMI 1640 to remove nonadherent cells, the plates were left in the sterilizer for another 60 minutes. From then on the method for quantification of the NO by the cells in culture was followed.

Nitrite quantification: Monocytes were treated with activating agent (LPS $-10 \mathrm{mg} / \mathrm{mL}$ for 24 hours) in 96 -well plates. NO2- concentration in culture supernatants was measured to assess NO production. Fifty $\mathrm{ml}$ of sample aliquots were mixed with $50 \mathrm{ml}$ of Griess reagent $(1 \%$ sulfanilamide $/ 0.1 \%$ naphthylethylene diamine dihydrochloride $/ 2 \%$ phosphoric acid) in 96 -well plate and incubated at $25^{\circ} \mathrm{C}$ for $10 \mathrm{~min}$. The absorbance at $550 \mathrm{~nm}$ was measured on a microplate reader. NaNO2 was used as the standard to calculate NO2- concentrations.

\section{Results}

The mean levels of nitric oxide (NO) produced by cultured monocytes of patients and control individuals are expressed in Table 1.

TABLE 1 - Mean levels of NO produced by monocytes $(\mu \mathrm{mol} / \mathrm{ml})$ of the four groups.

\begin{tabular}{lc}
\hline Groups: SMH; SMH/SLGV; SMH/SLGV/AI; and CG & Mean \pm SD \\
& $\mu \mathrm{mol} / \mathrm{ml}$ \\
\hline Carriers of hepatosplenic schistosomiasis mansoni (SMH) & $5.3 \pm 1.3$ \\
Splenectomized patients (SMH/SLGV) & $6.7 \pm 0.4$ \\
Spleen tissue auto implanted patients (SMH/SLGV/AI) & $7.4 \pm 1.6$ \\
Control group (CG) & $8.2 \pm 2.7$ \\
\hline
\end{tabular}




\begin{tabular}{lccc}
\hline Comparison & Mean Difference & $\mathbf{q}$ & Pvalue \\
\hline CGvs SMH/SLGV/AI & 0.77 & 1.615 & $\mathrm{P}>0.05$ \\
CG vs SMH/SLGV & 1.52 & 3.055 & $\mathrm{P}>0.05$ \\
CG vs SMH & 2.90 & 5.837 & $\mathbf{P}<\mathbf{0 . 0 1}$ \\
SMH/SLGV/AI vs SMH/SLGV & 0.75 & 1.503 & $\mathrm{P}>0.05$ \\
SMH/SLGV/AI vs SMH & 2.13 & 4.285 & $\mathbf{P}<\mathbf{0 . 0 5}$ \\
SMH/SLGV vs SMH & 1.38 & 2.681 & $\mathrm{P}>0.05$ \\
\hline
\end{tabular}

\section{Discussion}

Is it possible to control $S$. mansoni infection? There are several actions that combined could be adopted in the attempt of controlling schistosomiasis mansoni in Brazil. Among them: 1 - intermediary host' control through molluscicides or biological methods; 2 improvement of basic sanitation conditions and water potable supply; 3 - sanitary education for exposed population; 4 -individual or massive treatment of people in areas of high prevalence; 5 - individual protection against penetration of cercarias; 6 -vaccine for exposed people, if there is an efficient one ${ }^{2}$. The hurdles to overcome these actions are: 1 - intermediary hosts' control large dissemination and their escape mechanisms from molluscicides and from biological control, besides high costs and low efficacy; 2 - high costs associated with the implementation of sanitary conditions and water supply, and intense contact of rural population with polluted water, outside dwellings, in particular, in agricultural and fishing activities or other eventual activity; 3 - the long time needed for sanitary education and for community to adhere to controlling programs; 4 - individual or massive treatment has been shown efficient for controlling the morbidity, but not for reducing prevalence due to reinfections; 5 - until the present days, there not an effective vaccine for preventing schistosomiasis ${ }^{2}$. However, although these considerations are true, the main reason is the lack of political determination for bridging the huge social economic gap among social extracts of the Brazilian population. It must be stressed that all volunteers of the four groups included in this research lives in rural area, come from low income social extract and present low level of education. Basic education for all people, especially for the low income population, would be the starting point for solving this important social health problem in some states of Brazil, including Pernambuco ${ }^{3}$. Better economic distribution would follow. These basic steps would be important to control this world neglected disease, prevalent in several countries including Brazil ${ }^{1}$. The knowledge about the downstream effector cells that regulate inflammatory responses and how their functional activity is controlled by the immune response may reveal new and/or improved approaches for disease intervention in genera $1^{18}$. NO is implicated as an integral component of the host armament against invading parasites. In case of $S$. mansoni infection NO plays a role in regulating of egg-induced inflammation, preventing liver hepatic cell death and widespread tissue damage. However, in spite of this important role $\mathrm{NO}$ production requires tight control to limit cytotoxic damage to the host" own cells. Unregulated production may lead to a variety of damaging effects, including alterations to neurological functions ${ }^{11}$. In NO synthase-2 (NOS-2) deficient mice sensitized with $S$. mansoni eggs/IL-12 not only fail to control their egg-induced inflammatory response, but actually display a marked exacerbation in the reaction despite developing a Th1-deviated response ${ }^{18}$. NOS-2 remained the dominant although not exclusive, response in mice infected by $S$. mansoni ${ }^{18}$. For example, when NOS2 is induced in mice sensitized with $S$. mansoni eggs and IL-12, the animals develop smaller and much less fibrotic granulomas when subsequently infected ${ }^{19}$. There is a beneficial role for NOS-2 in the regulation of liver inflammation regarding $S$. mansoni infection, suggesting that the ultimate success of Th2-toTh1 immune deviation strategies of the host will rely on the efficient activation of NOS-2 expression in downstream effector cells ${ }^{19}$. It is important to stress that some eggs laid by adults $S$. mansoni pairs are trapped in the liver, a process that can lead to marked inflammation, tissue eosinophilia, collagen deposition, and ultimately portal hypertension and severe hepatic fibrosis in some patients ${ }^{18}$. Nitric oxide levels can up or down regulate the liver inflammatory process and produce immune deviation, specially considering that the treated patients persists living in the same environment an are at risk of suffering a new infection (reinfection). In this regard, it is important that the mean NO levels by monocytes of the study group (SMH/SLGV/ $\mathrm{AI})$ was similar to that of the control group (CG). NO, a molecule produced by numerous cell types including monocytes, is implicated in a wide range of disease processes, exerting both detrimental and beneficial effects at the cellular and vascular levels. Sepsis is one area where NO is thought to play a key role in pathogenesis. Importantly, most NO research has been conducted on animal models. In attempting to understand the complexities of NO in sepsis and interpret the many apparently conflicting results available. The situation can vary according to the species being studied, the model of sepsis employed, and the concentrations of NO involved. Also, the timing of measurements and observations may vary according to the type of receptor blockade employed ${ }^{20}$. The pathogenic role of NO in overwhelming infection and septic shock can, in fact, 
encompass both vascular alterations and the direct cellular toxic effects of NO or NO-related compounds. At high concentrations, NO becomes a potential proinflammatory and cytotoxic factor by reacting with $\mathrm{O}^{2-}$ to form the toxic product, peroxynitrite, and may cause tissue damage. In several experimental models, endotoxin has been shown to increase the constitutive release of NO by the endothelium and the activity of the nitric oxide synthase isoforms (iNOs\} enzyme ${ }^{20}$. Mice lacking iNOS have been reported to be resistant to endotoxin-induced mortality ${ }^{21}$ and vascular hypocontractility ${ }^{22}$, supporting a key role for iNOS in endotoxin shock. In addition to endotoxin, cell wall components and enterotoxin from gram-positive organisms are also able to stimulate NO release ${ }^{20}$. Considering that patients suffering from different diseases who underwent splenectomy are at risk of overwhelming post splenectomy severe infection ${ }^{6}$ it is important to consider that patient carriers of hepatosplenic schistosomiasis mansoni who undergo this surgical procedure for decompressing the portal pressure should remain with residual spleen tissue; this is specially true for children. We have shown that several functions of monocytes in patients from the study group remain similar to those from control individuals without $S$. mansoni infection ${ }^{5,7,8}$. It may be important to consider that these patients, at long term follow-up are also presenting improvement in the liver function, this is again true even for those who persisted with residual infection, and have received a second medical treatment with praziquantel $^{23}$. It is well known that good hepatic functional reserve is important in providing immune response to infection. The patient carriers of the chronic hepatosplenic form of schistosomiasis mansoni presented the lower levels of NO production by monocytes. This has been observed in some parasite disease, including schistosomiasis. Usually the NO levels are high in the acute phase of the disease and decreases in the chronic stage ${ }^{24}$. On the other hand, the patients from the study group presented with no different mean level of NO production by monocytes when it is compared with that of the individuals from the control group. There is no available information that maintaining splenic residual function by providing splenosis after splenectomy is associated to NO production by monocytes. However, while the mean level of the NO production by monocytes from patients of the study group was significant greater $(q=4.285 \mathrm{p}<0.05)$ than the one of patients with hepatosplenic schistosomiasis mansoni; this did not happen when the mean results of the solely splenectomized patients were compared with that of the later patients $(q=2.681 \mathrm{p}>0.05)$.

\section{Conclusion}

Collectively, the results point to a restoration of $\mathrm{NO}$ normal production by monocytes in SHM patients who underwent medical and surgical treatments, especially in those who had received auto implantation of spleen tissue in the major omentum after splenectomy and ligature of the left gastric vein. The data gives further support to the hypothesis that this additional procedure is important in the restoration of the immune response of these patients, since NO synthesis by the monocytes correlates with protective immunity against infection; thus, protecting them against overwhelming post splenectomy infection.

\section{References}

1. WHO - World Health Organization. The Control of Schistosomiasis. Technical Report Series; 1993.

2. Coura JR, Amaral RS. Epidemiological and control aspects os schistosomiasis in Brazilian endemic áreas. Mem Inst Oswaldo Cruz. 2004; 99: 13-9.

3. Resendes APC, Souza-Santos R, Barbosa CS. Internação hospitalar e mortalidade por esquistossomose mansônica no Estado de Pernambuco, Brasil, 1992/2000. Cad Saúde Pública. 2005; 21: 1392-401.

4. Ferraz AAB, Lopes EPA, Barros FMR, Sette MJA, Arruda SMB, Ferraz EM. Esplenectomia com ligadura da veia gástrica esquerda e desvascularização da grande curvatura do estômago no tratamento da esquistossomose hepatoesplênica. É necessária a escleroterapia endoscópica pós-operatória? Arq Gastroenterol. 2001; 38: 84-8.

5. Brandt CT, Maciel DT, Frei Caneca AO, Castro CMMB, Araújo LB. Autotransplant of spleen tissue in children with schistosomiasis: evaluation of splenic function after splenosis. Mem Inst Oswaldo Cruz. 2001; 96: 117-21.

6. Kyaw MH, Holmes EM, Toolis F, Wayne B, Chalmers J, Jones IG, Campbell H. Evaluation of severe infection and survival after splenectomy. Am J Med. 2006; 119: 1-7.

7. Brandt CT, Leite CRC, Castro RM, Brandt Filho C, Castro FMM, Castro CMMB. Aderência e atividade microbicida de monócitos em portadores de esquistossomose mansônica na forma hepatoesplênica cirúrgica. Acta Cir Bras. 2003; 18: 143-53.

8. Brandt CT, Leite CRC, Castro RM, Brandt Filho C, Castro FMM, Castro CMMB. Avaliação do efeito da esplenectomia e auto-implante esplênico sobre algumas funções de monócitos em crianças com esquistossomose mansônica. Rev Soc Bras Trop. 2005; 38: 38-42.

9. McCormick PA. Pathophysiology and prognosis of oesophageal varices. Scand J Gastroenterol. 1994; 207: 1-4.

10. Oliveira DM, Silva-Teixeira DN, Carmo AS, Góes AM. Role o nitric oxide on human schistosomiasis mansoni: upregulation of in vitro granuloma formation by $\mathrm{N}-$ nitro-L-arginine methyl ester. Nitric Oxide Biol Chem. 1998;2:57.

11. Brunet LR, Beal M, Dunne DW, Pearce EJ. Nitric oxide and $\mathrm{Th} 2$ response combine to prevent severe hepatic damage during Schistosoma mansoni infection. J Immunol. 1999; 163: 4976-84.

12. Brunet LR. Nitric oxide in parasitic infection. Int Immunopharmacol. 2001; 1: 1457-67.

13. Neves SM, Rezende SA, Goes AM. Nitric oxidemediated immune complex-induced prostaglandin $\mathrm{E}(2)$ production by peripheral blood mononuclear cells of human infected with Schistosoma mansoni. Cell Immunol. 1999; 195: 37-42. 
14. Oliveira DM, Silva-Teixeira DN, Gustavson S, Oliveira SM, Goes AM. Nitric oxide interaction with IL-10, MIP1alpha, MCP-1 and RANTES over the in vitro granuloma formation against different Schistosoma mansoni antigenic preparations on human schistosomiasis. Parasitology. 2000; 120: 391-8.

15. Clancy RM, Leszczynska-Piziak J, Abramson SB. Nitric oxide, an endothelial cell relaxation factor, inhibits neutrophil superoxide anion production via a direct action on the NADPH oxidase. J Clin Invest. 1992; 90: 1116-121.

16. Panas D, Khadour Szabo FH, Szabo C, Schulz R. Proinflammatory cytokines depress cardiac efficiency by a nitric oxide-dependent mechanism. Am J Physiol. 1998; 275:H1016-123.

17. Chandra A, Enkhbaatar P; Nakano Y, Traber LD, Traber DL. Sepsis: emerging role of nitric oxide and selectins. Clinics. 2006; 61: 71-6.

18. Hesse M, Modolell M, La Flamme AC, Schito M, Fuentes JM, Cheever AW, Pearce EJ, Wynn TA. Differential regulation of nitric oxide synthase- 2 and arginase 1 by type 1 /type 2 cytikines in vivo: Granulomatous pathology is shaped by the pattern of L-arginine metabolism. J Immunol. 2001;67: 6533-44.
19. Hesse M, Cheever AW, Jankovic D, Wynn TA. NOS-2 mediates the protective anti-inflammatory and antifibrotic effects of the Th-1-inducing adjuvant, IL12 , in a Th2 model of granulomatous disease. Am J Pathol. 2000; 157: 945-55.

20. Graier WF, Myers PR, Rubin LJ, Adams HR, Parker JL. Escherichia coli endotoxin inhibits agonist-mediated cytosolic $\mathrm{Ca}^{2+}$ mobilization and nitric oxide biosynthesis in cultured endothelial cells. Circ Res. 1994;75:659-68.

21. Wei XQ, Charles IG, Smith A, Ure J, Feng GJ, Huang FP, et al. Altered immune responses in mice lacking inducible nitric oxide synthase. Nature. 1995;375:408-11.

22. Gunnett CA, Chu Y, Heistad DD, Loihl A, Faraci FM. Vascular effects of LPS in mice deficient in expression of the gene for inducible nitric oxide synthase. Am J Physiol. 1998; 275:H416-21.

23. Brandt CT, Braga MVM, Melo KL. Surgical hepatosplenic mansonic schistosomiasis in adolescents: repercussions of the post-treatment schistosomotic burden on the hepatic functional reserve. Mem. Inst. Oswaldo Cruz. 2001; 96:113-5.

24. Abo-Shousha S, Khalil SS, Rashwan EA. Oxygen free radical and nitric oxide production in single or comvined human schistosomiasis and fascioliasis. J Egypt Soc Parasitol. 1999; 29: 149-56.

\section{Correspondence:}

Carlos Teixeira Brandt

Avenida Boa Viagem, 5090/1201

51011000 Recife-PE Brazil

carlosbrandt@,bol.com.br
Conflict of interest: none Financial source: none

Received: April 02, 2006

Review: May 11, 2006

Accepted: June 17, 2006

\section{How to cite this article:}

Brandt CT, Leite CRC, Manhaes-de-Castro FM, Macedo EMC, Silva RPP, Castro CMMB. Nitric oxide monocyte production levels in patients with the hepatosplenic form of Scistosoma mansoni infection who underwent splenectomy, ligature of the left gastric vein and auto implantation of spleen tissue in the major omentum. Acta Cir Bras. [serial on the Internet] 2006 Sept-Oct;21(5). Available from URL: http://www.scielo.br/acb. 